\title{
RE-AKTUALISASI KISAH PERJALANAN LAKSAMANA CHENG HO DI CIREBON MELALUI BATIK (Kajian Batik di Cirebon serta hubungannya dengan Bahasa Rupa Tradisi)
}

\author{
Amanda Rizky¹ (Institut Teknologi Bandung)
}

\begin{abstract}
Admiral Cheng Ho (Zheng He), one of the migrants from China who introduced his culture to the Indonesians. Cirebon has benefited greatly from its expedition. However, not much remains of Admiral Cheng Ho still preserved by Cirebon. Whereas Admiral Cheng Ho has contributed a lot of useful knowledge to the port and the kingdom in Cirebon, which at that time port of Cirebon known as the Port of Muara Jati became famous throughout Java and even abroad. Preserving the history of Admiral Cheng Ho's journey and its relics in Cirebon can enrich the cultural treasures to the Indonesian nation. One effort to preserve it is with batik, because batik is one of the cultural image of the Indonesian nation that easy to spread widely and the variety of Cirebon batik decoration is influenced by the ornaments from China. In order to create a textile that can tell the journey of Admiral Cheng Ho, this research will use comparative study with qualitative methods to find linkages between batik in Cirebon and Bahasa Rupa Tradisi, which later will be applied to the design. The collaboration of travel story of Admiral Cheng Ho and batik will create contemporary art that communicative and gives a new breath for Indonesian textile.
\end{abstract}

Keywords: admiral cheng ho, bahasa rupa tradisi, batik, cirebon, re-actualizasion

\begin{abstract}
ABSTRAK
Laksamana Cheng Ho (Zheng He), salah satu pendatang dari Cina yang memperkenalkan budayanya kepada bangsa Indonesia. Cirebon banyak memetik keuntungan dari ekspedisinya. Namun, tidak banyak peninggalan Laksamana Cheng Ho yang masih dilestarikan oleh Cirebon. Padahal Laksamana Cheng Ho telah banyak berkontribusi memberikan ilmu pengetahuan yang berguna untuk pelabuhan dan wilayah kerajaan di Cirebon, yang pada masa itu pelabuhan Cirebon dikenal sebagai Pelabuhan Muara Jati menjadi terkenal di seantero Jawa bahkan mancanegara. Melestarikan sejarah perjalanan Laksamana Cheng Ho dan peninggalannya di Cirebon dapat memperkaya khasanah kebudayaan bangsa Indonesia. Salah satu upaya untuk melestarikannya adalah dengan batik, karena batik merupakan salah satu citra budaya bangsa Indonesia yang mudah menyebar luas dan ragam hias batik Cirebon banyak dipengaruhi oleh ragam hias dari Cina. Demi menciptakan tekstil yang bisa menceritakan perjalanan Laksamana Cheng Ho, maka penelitian ini akan meggunakan strategi studi komparatif dengan metode kualitatif untuk menemukan keterkaitan antara batik di Cirebon dan Bahasa Rupa Tradisi, yang nantinya akan diaplikasikan pada perancangan. Kolaborasi kisah perjalanan Laksamana Cheng Ho dan batik akan menciptakan karya seni rupa kontemporer yang komunikatif dan memberikan nafas baru bagi tekstil Indonesia.
\end{abstract}

Kata kunci: bahasa rupa tradisi, batik, cirebon, laksamana cheng ho, re-aktualisasi 


\section{PENDAHULUAN}

Pengaruh kebudayaan Cina di Indonesia salah satunya berkembang melalui barang-barang buatan Cina seperti porselin, manik-manik, barang-barang logam, kayu dan tekstil. Kedinamisan gambar atau ragam hias pada barang seni yang populer saat itu seperti guci dari Cina menarik perhatian kaum muslim di pesisir utara pulau Jawa, sehingga beberapa guci dan karya seni lainnya tersebut dihargai dan dipakai oleh mereka untuk dipajang di beberapa tempat penting. Kedinamisan dan keindahan dari ragam hias Cina mempengaruhi corak yang terdapat pada benda pusaka istana kerajaan Cirebon. Benda pusaka tersebut diukir dengan gaya Cina. Pada awal perkembangan Islam inilah pengaruh kebudayaan Cina sangat kuat, keterlibatan pendatang muslim Cina yang mengembangkan islam di pesisir utara pulau Jawa dianggap banyak mendorong kemajuan islam dan ikut bergerak dalam memperlacar perdagangan masyarakat Cirebon dengan mancanegara. Pembauran antara orang Cina dengan penduduk pribumi dilandasi terutama oleh keagamaan dan sifat bangsa Indonesia yang terbuka dan ramah. Akibat dari pembauran tersebut, mereka dapat bekerja sama dalam berbagai hal dengan tujuan untuk kemakmuran bersama.

Cirebon merupakan salah satu tempat yang dikunjungi oleh pendatang dari Cina, yang paling dikenal adalah Laksamana Cheng $\mathrm{Ho}$, atau secara internasional nama Cheng Ho menjadi Zheng He. Laksamana Cheng Ho dalam misi penyebaran Islam di kawasan Asia Tenggara, ia dan pasukannya mendatangi Cirebon tahun 1405. Pada pelayaran pertamanya ia mengisi air bersih untuk keperluan armadanya. Armada ini mengangkut ribuan ton barang-barang khas dari Cina untuk diperdagangkan dan hadiah. Namun, karena dengan kapal-kapalnya besar dan jumlah penumpangnya berjumlah besar, mengisi air untuk armada Cheng Ho membutuhkan waktu yang lama. Maka ia membutuhkan izin dari penguasa lokal untuk singgah di wilayah tersebut dalam waktu yang lama. Dari sanalah awal persahabatan Cirebon dengan Laksamana Cheng Ho. Laksamana Cheng Ho memberikan hadiah kepada Cirebon berupa guci dan piringpiring dengan lafaz tauhid, kenang-kenangan tersebut kini disimpan dalam museum benda pusaka Kesultanan Kasepuhan.

Filolog Cirebon Raden Raffan Safari Hasyim dalam artikeL INDOPOS (2018) menyebutkan, selain penyebaran Islam, kedatangan Laksamana Cheng Ho membawa misi pertukaran komoditas, pasukan Laksamana Cheng Ho juga memberikan ilmu pengetahuan tentang kesyahbandaran di sekitar Pelabuhan Muara Jati dan wilayah Kerajaan Sing Apura. Salah satunya membangun mercusuar untuk mempermudah dalam mengontrol Pelabuhan Muara Jati. Setelah dibangun mercusuar, makin ramailah Pelabuhan Muara Jati sehingga terkenal di seantero Jawa, bahkan mancanegara. Laksamana Cheng Ho dianggap sebagai penjalin hubungan baik antara Cirebon dan Cina hingga generasi-generasi setelahnya. Menurut naskah Purwaka Caruban Nagari, armada Laksamana Cheng Ho bersama Ma Huan, penulis dan penerjemahnya yang beragama Islam, Laksamanna Cheng Ho datang ke Cirebon membawa 63 kapal dengan 23.000 anggota pasukan. Meski sempat lama singgah di Cirebon, tidak banyak petilasan Laksamana Cheng Ho di daerah tersebut. Masih ada sedikit peninggalan berupa teknologi pada zamannya yang dibuat Laksamana Cheng Ho yaitu bekas mercusuar di kawasan Muara Jati yang sudah roboh pada zaman Belanda,

Kini satu-satunya landmark Laksamana Cheng Ho di Cirebon adalah bangunan modern berupa replika kapal yang dibangun pengusaha Cirebon keturunan Tionghoa. Yakni restoran 
berupa replika kapal Laksamana Cheng Ho yang dibangun persis di pinggir laut namun selain bangunannya yang berbentuk kapal Laksamana Cheng Ho, tidak ada lagi unsur sejarah yang diperkenalkan dan restoran tersebut merupakan milik perseorangan, bukan hasil kelola atau milik bersama masyarakat Cirebon. Maka dari itu perlu adanya pelestarian sejarah Laksamana Cheng Ho dari masyarakat Cirebon yang tidak hanya berupa landmark atau benda pajang, tetapi sesuatu yang bisa masyarakat buat, mudah diperkenalkan ke luar Cirebon sekaligus memberi keuntungan secara ekonomi. Melihat peluang bahwa Cirebon merupakan daerang penghasil batik, kisah Laksamana Cheng Ho dapat diceritakan melalui batik yang memiliki sifat mudah menyebar ke berbagai penjuru Indonesia bahkan luar negeri. Batik dengan kisah perjalanan Laksamana Cheng Ho ini akan menjadi batik kontemporer yang mampu menceritakan kisah perjalanan Laksamana Cheng Ho selama di Cirebon dengan sistem penggambaran tertentu dan ragam hias dari Cirebon-Cina pada masa Laksamana Cheng Ho berada di Cirebon.

Unsur narasi ternyata memang sudah digunakan pada berbagai corak yang dikaitkan dengan legenda masa kejayaan kerajaan Cirebon pada Batik Trusmi periode 1925-1980an yaitu batik motif kereta kencana, paksi naga liman, wadasan sunyaragi, naga seba, balongan sunyaragi, mega mendung dan sebagainya (Pandanwangi, 2002). Pada penelitian tersebut, sistem penggambaran yang menjadi pedoman atau penerjemah raga hias yang terkandung pada batik. Sistem penggambaran Bahasa Rupa Tradisi sudah ditemukan pada zaman purba, Bahasa Rupa sendiri merupakan penelitian dari Prof. Primadi Tabrani.

$$
\text { Kajian Batik di Cirebon serta }
$$
hubungannya dengan Bahasa Rupa Tradisi ini nantinya akan menjadi data untuk perancangan batik kisah perjalanan Laksamana Cheng Ho dengan menggunakan sistem penggambaran Bahasa Rupa Tradisi. Perancangan tersebut merupakan sebuah usaha yang diharapkan dapat melestarikan peninggalan sejarah untuk memperkaya khasanah kebudayaan bangsa Indonesia terutama untuk Cirebon dan melestarikan Bahasa Rupa yang merupakan sistem menggambar yang dianut oleh seni rupa tradisi Indonesia sejak zaman dahulu. Perancangan ini juga dapat menjadi referensi untuk penelitian dan perancangan selanjutnya. Perancangan ini oleh penulis dianggap penting karena belum banyak batik yang mengandung narasi sejarah. Sedangkan penelitian dengan studi komparasi dengan metode kualitatif yang dibahas sekarang ini akan menjadi bahan kelengkapan untuk memperkaya data dan memperkuat relevansi penggabungan Bahasa Rupa dan batik.

\section{Rumusan Masalah dan Tujuan}

Kehadiran bangsa Cina di Indonesia, telah banyak membawa pengaruh terhadap perkembangan kebudayaan dan kesenian, terutama terlihat dari unsur-unsur ragam hias Cina yang memengaruhi ragam hias batik Cirebon. Dalam beberapa literatur disebutkan bahwa hal tersebut dipengaruhi oleh berbagai faktor antara lain: (1) letak geografis daerah pembuat batik, (2) pranata sosial, (3) kepercayaan dan adat istiadat, (4) keadaan alam, termasuk flora dan fauna, dan (5) adanya kontak kebudayaan Indonesia dengan Cina. Cirebon merupakan salah satu tempat yang dikunjungi oleh pendatang dari Cina, yang paling dikenal adalah Laksamana Cheng Ho. Berbagai interaksi dan kontribusinya, Laksamana Cheng Ho sedikit banyak telah memengaruhi ragam hias Cirebon dengan budaya-budaya Cina. Laksamana Cheng Ho yang datang ke tempat ia jajaki dikenal sebagai seseorang yang bersifat simbiosis mutualisme 
tidak bersifat penjajah, mejadikan masyarakat yang tanahnya di jajakinya senang dengan kehadirannya dan menjaga peninggalanpeninggalannya.

Namun, di Cirebon tidak banyak pelestarian peninggalan Laksamana Cheng Ho dibanding dengan wilayah lain yang dijajakinya. Satu-satunya landmark yang mengingatkan Laksamana Cheng Ho hanya restoran menengah keatas yang dibangun milik pribadi, bukan tempat yang dapat dikunjungi secara bebas. Berangkat dari fenomena inilah yang mendasari perancang untuk menciptakan suatu usaha untuk melestarikan sejarah Laksamana Cheng Ho, sesuatu yang bisa masyarakat buat, mudah diperkenalkan ke luar Cirebon sekaligus memberi keuntungan secara ekonomi. Cirebon yang kaya dan terkenal dengan ragam hiasnya maka berpotensi untuk mengembangkan atau memperkaya ragam hias menjadi batik yang mengandung narasi.

Tujuan perancangan ini mempunyai dua tujuan; pertama, untuk melestarikan kisah perjalanan Laksamana Cheng Ho di Cirebon kepada masyarakat terutama untuk generasi muda sebagai generasi yang akan terus melestarikan sejarah agar dapat dinikmati oleh generasi mendatang dan memperkenalkan batik yang mengandung narasi sejarah dengan sistem penggambaran Bahasa Rupa. Penggabungan batik dan Bahasa Rupa akan menciptakan karya seni rupa kontemporer yang komunikatif dan memberikan nafas baru bagi tekstil Indonesia.

\section{METODOLOGI}

Penelitian ini nantinya akan dijadikan bahan penyusun penelitian selanjutnya yaitu sebuah perancangan yang menghasilkan sebuah produk atau karya sebagai solusi permasalahan penelitian, Adapun beberapa aktivitasnya adalah sebagai berikut:
Pengumpulan data yang dilaksanakan dengan strategi studi komparatif yaitu perbandigan beberapa batik yang mengandung Bahasa Rupa tradisi. Penelitian ini juga bersifat kualitatif yaitu melalui studi literatur, khususnya data mengenai batik yang terfokus pada batik Cirebon, sejarah Laksamana Cheng Ho di Cirebon dan pengamatan pada ragam hias Cirebon - Cina pada masa kedatangan Laksamana Cheng Ho ke Cirebon beserta peninggalannya. Hal ini dilakukan untuk memperoleh data yang relevan untuk perancangan batik kisah perjalanan Laksamana Cheng Ho di Cirebon. Melakukan observasi dengan mengunjungi lokasi yang diperlukan untuk penelitian di Cirebon, seperti lokasi bekas peninggalan Laksamana Cheng Ho yang pernah dibangun dan museum-museum yang berkaitan dengan penelitian. Wawancara praktisi dan pakar dari batik dan Bahasa Rupa. Jika ada, peneliti akan mencoba wawancarai beberapa narasumber untuk melengkapi sejarah Laksamana Cheng Ho khususnya di Cirebon.

Kajian teori yang relevan melalui kajian teoritis yang mempertemukan prinsip-prinsip dari Bahasa Rupa dengan batik.

\section{Data}

\section{Terjadinya Hubungan Indonesia dangan Cina}

Pada masa prasejarah, bangsa Indonesia dikenal sebagai bangsa pelaut dan pedagang yang terbiasa mengarungi Samudera India dan Samudera Pasifik. Bangsa Indonesia melakukan tukar-menukar barang yang dibutuhkan dari satu pulau ke pulau lainnya. Kepulauan Indonesia letaknya sangat strategis bagi pelayaran dan perdagangan dunia. Bangsa-bangsa lain banyak yang singgah dan berdagang di tanah air kita. Jalur perdagangan dunia pada zaman lampau melalui dua jalur, yaitu jalur darat dan jalur laut. Jalur darat disebut jalan sutera, karena barang utama yang diperdagangkan adalah kain sutera 
buatan China yang sangat mahal harganya. Adapun jalur kedua adalah jalan melalui laut. Jalur laut ini dimulai dari Cina melalui perairan Indonesia dan Selat Malaka menuju India. Dari India ini kemudian ada yang ke Teluk Persia melalui Suriah ke Laut Tengah dan ada pula yang melalui Laut Merah sampai Laut Tengah.

Pada awal abad pertama masehi, perdagangan antara Cina, India, dan daerah sekitar Laut Tengah melalui jalan sutera sangat ramai. Namun jalan darat ini menjadi tidak aman akibat banyaknya perampok. Para pedagang kemudian beralih melalui jalan laut yang terdekat, yaitu antara India dengan Cina dan berlabuh di Selat Malaka. Jalur perdagangan melalui Selat Malaka menjadi ramai, maka bermunculanlah bandar-bandar tempat para pedagang menjual dan membeli barang dagangan. Di Selat Malaka ini banyak pula para pedagang dari Indonesia, yang turut serta dalam perdagangan tersebut. Dalam perkembangan selanjutnya, hubungan dagang antara India dan Cina berkembang semakin pesat. Dari Cina, India memperoleh sutera dan barang-barang porselen. Sedangkan India banyak mengekspor barang-barang dari gading, tenunan halus, dan barang ukiran. Kontak perdagangan ini melibatkan pula para pedagang Indonesia. Para pedagang India dan Cina ini banyak yang membeli barang dagangan dari Indonesia, yaitu rempahrempah, kayu cendana, emas, perak dan lainlain. Cengkeh yang ketika itu merupakan salah satu hasil kepulauan Indonesia bagian timur menjadi barang dagangan yang sangat dicari oleh para pedagang India.

\section{Pengaruh hubungan ini kepada ragam hias Cina pada tekstil Nusantara}

Kecenderungan tekstil Nusantara masa prasejarah mencerminkan pandangan hidup yang menekankan keseimbangan, keselarasan, keserasian, dan kelestarian. Ragam hias tekstil Nusantara dibentuk bukan hanya sekedar untuk memenuhi kebutuhan teknis, estetis dan fungsi saja, tetapi selalu dihubungkan dengan kekuatan gaib, yang dilambangkan dalam bentuk ragam hias yang dekoratif dan simbolis.

Bangsa Indonesia memiliki tradisi yang bersifat "dualisme dwi-tunggal" (Primbadi Tabrani, 1995). Ada dunia atas: dewa, angkasa, gunung, lelaki, baik, kanan, dan sebagainya. Sebagai pasangannya, ada dunia bawah: manusia, laut, wanita, jahat, kiri, dan sebagainya. Dualisme ini bukan untuk dipertentangkan tapi untuk diintegrasikan.

Selain itu, berkembang pula pandangan dualisme: lama - baru, kenal asing, dalam - luar. Dualisme itu bukan untuk dipertentang-tentangkan. Mereka perlu kerja sama untuk menciptakan paduan yang seimbang, selaras, serasi, dan lestari, kepada sesuatu yang baru, asing, luar, bangsa Indonesia tidak langsung menolaknya, tetapi mencoba menjalin hubungan dengannya kemudian mengintegrasikannya untuk menjadi "milik barunya" tanpa meninggalkan jati dirinya. Salah satunya hal ini tercermin dalam ragam hias Nusantara. Kekayaan ragam hias sejak masa prasejarah, yang kemudian ditambah dengan bentuk ragam hias paduan budaya Cina dan India, merupakan variasi yang sangat menarik karena memadukan budaya antar bangsa. Keragaman bentuk ragam hias sangat dipengaruhi oleh faktor adat istiadat yang berbeda, situasi, kondisi dan senimannya. Tidak hanya itu yang menjadikan ragam hias batik bervariasi, tetapi kebutuhan terhadap ragam hias juga termotivasi oleh kebutuhan artistik.

Daya artistik yang besar terungkap dalam segala rupa ciptaan artistik dan kerajinan yang sangat indah (Mochtar Lubis, 1997). Konsep artistik dalam tradisi Indonesia sangat luas, tidak hanya kulitnya saja, tetapi juga isi yang padu, sehingga tercapailah keseimbangan, keselarasan, keserasian, dan 
kelestarian. Konsep artistik tradisi seni rupa Indonesia adalah perwujudan dari nilai-nilai integral sebagai perpaduan dari dualisme yang saling melengkapi. Karena itu, seni rupa tradisional Indonesia banyak terungkap dalam bentuk ragam hias yang bersifat dekoratif, simbolik dan dinamis (Hasanudin, 2001). Ragam hias adalah bagian yang tak terpisahkan dari ciri tekstil Indonesia. Ragam hias juga menggambarkan adanya berbagai suku bangsa. Maka dari itu, bangsa Indonesia memiliki kebinekaan ragam tekstil yang menggambarkan kekayaan budaya bangsa Indonesia.

\section{Laksamana Cheng Ho}

Laksamana Cheng Ho (dikenal juga dengan nama Zheng He) lahir pada tahun 1371 Masehi di Provinsi Yunan, di bagian Barat Daya Tiongkok yang sekarang diketahui. Laksamana Cheng Ho lahir dan tumbuh dari keluarga muslim. Ayahnya bahkan pernah menunaikan ibadah haji ke tanah Suci, Mekah. Ketika berusia 10 tahun, terjadi pergolakan di tanah Tiongkok. Laksamana Cheng Ho dan anak-anak lain seumurannya ditangkap oleh sekelompok tentara yang menginvasi wilayah Yunan. Tiga tahun kemudian, mereka lalu dipekerjakan sebagai pelayan rumah tangga oleh Pangeran Zhu Di, putra keempat dari Kaisar Tiongkok yang berkuasa pada masa itu. Laksamana Cheng Ho, secara istimewa, menjadi pelayan khusus Pangeran Zhu Di. Dari sanalah pintu masuk Laksamana Cheng Ho menuju karir militernya terbuka lebar. Pergaulannya dengan Pangeran Zhu Di membuat Laksamana Cheng Ho belajar banyak hal, mulai dari diplomasi hingga seni perang. Ketika Pangeran Zhu Di diangkat menjadi Kaisar Tiongkok pada tahun 1402, Laksamana Cheng Ho sebagai abdinya yang paling setia turut mendapatkan kenaikan derajat. Kaisar Zhu Di menunjuknya menjadi seorang laksamana, lalu memberinya misi untuk menjelajahi dunia. Laksamana Cheng
Ho adalah abdi istana pertama yang memiliki posisi tinggi dalam militer Tiongkok kala itu.

Tak banyak orang yang sadar bahwa selain Bangsa Arab dan India, Bangsa Tiongkok juga merupakan salah satu bangsa pendatang yang turut menyebarkan agama Islam di nusantara. Islam yang dibawa Bangsa Tiongkok menyebar melalui akulturasi budaya, baik yang terjadi lewat perdagangan maupun pernikahan antar-etnis. Salah satu komunitas Tionghoa yang berperan menyebarkan Islam di Kota Palembang tak lain adalah armada Laksamana Cheng Ho. Sebagian sejarawan kerap menyebut Laksamana Cheng Ho sebagai seorang muslim yang taat. Sebelum menggelar pelayaran pertamanya pada tahun $1405 \mathrm{M}$, Laksamana Cheng Ho dan rombongan besarnya yang beragama Islam terlebih dahulu melaksanakan sholat di sebuah masjid di Kota Quanzhou, Provinsi Fujian. Dalam pelayaran pertamanya, Laksamana Cheng Ho dan armada yang dipimpinnya mencapai Kalkuta (India), Srilangka, Vietnam, Semenanjung Malaya, Sumatera dan Jawa. Di setiap lokasi yang mereka capai, armada Laksamana Laksamana Cheng Ho singgah untuk waktu beberapa lama dan melakukan perdagangan barter dan pertukaran budaya dengan penduduk lokal. Konon lewat cara inilah Islam di Kota Palembang menyebar. Setelah sukses melakukan ekspedisi di nusantara, Laksamana Cheng Ho memimpin armadanya pulang ke Tiongkok pada tahun 1407 M. Pelayaran kedua armada Laksamana Cheng Ho berlanjut pada tahun yang sama, namun Cheng Ho tidak memimpin armadanya karena ia bertugas merenovasi masjid di kampung halamannya. la baru naik kembali ke geladak kapalnya setelah tugas merenovasi masjidnya selesai pada ekspedisi ketiga di tahun 1409 M.

Laksamana Cheng Ho dan armadanya kembali mencapai India dan Srilangka pada ekspedisi ketiga di tahun 1409 M - 1411 M. Laksamana Cheng Ho mulai menjamah Benua 
"Hitam" Afrika pada ekspedisi keempat, kelima dan keenamnya sepanjang tahun $1413 \mathrm{M}$ hingga 1422 M. Laksamana Cheng Ho menancapkan bendera Dinasti Ming di Aden, Teluk Persia dan Mogadishu. Ekspedisi terakhir yang dilakukan Laksamana Cheng Ho berlangsung pada tahun $1431 \mathrm{M}-1433 \mathrm{M}$, dimana ia berhasil mencapai Laut Merah. Ekspedisi Laksamana Cheng Ho yang luar biasa tersebut termaktub dalam buku Zheng He's Navigation Map. Terdapat 24 peta navigasi dalam buku tersebut yang meliputi arah pelayaran, jarak pelayaran dan daftar berbagai pelabuhan. Total jarak pelayaran armada Cheng Ho yang tercatat adalah 35.000 mil.

Ekspedisi Laksamana Cheng Ho berpengaruh bukan hanya pada wilayahwilayah yang disinggahinya, melainkan juga bagi Kerajaan Tiongkok sendiri. Catatan pelayaran Laksamana Cheng Ho turut memperkaya informasi yang dimiliki Tiongkok tentang peta lautan. Jalur perdagangan Tiongkok pun berubah, tidak sekedar bergantung pada Jalur Sutera yang membentang di daratan sepanjang Beijing hingga Bukhara. Berbeda dengan penjelajah Barat yang kerap mempraktikkan penindasan dan dominasi pada wilayah yang disinggahi, Laksamana Cheng Ho dan armadanya tidak menekankan kekuatan militer di setiap persinggahan mereka. Kekuatan militer mereka hanya dikerahkan ketika armada Laksamana Cheng Ho berhadapan dengan perompak di sepanjang jalur penjelajahan. Prinsip tersebut beranjak dari tujuan dari misi lain yang dibawa Laksamana Cheng Ho, yaitu untuk memperkenalkan keagungan Kaisar Zhu Di dan Dinasti Ming yang memimpin Tiongkok pada masa itu. Laksamana Cheng Ho tutup usia di Caliut, India, dalam perjalanan pulangnya dari ekspedisi terakhir di Laut Merah. Meski demikian, tak sedikit pula yang meyakini Laksamana Cheng Ho wafat di kampung halamannya pada tahun 1835 setibanya dari ekspedisi terakhir.

\section{Laksamana Cheng Ho di Indonesia}

Ekspedisi Laksamana Cheng Ho turut menyisakan banyak peninggalan di seluruh nusantara. Laksamana Cheng Ho memang pantas diidentikkan sebagai simbol akulturasi. Sebagai seorang tionghoa yang diyakini memeluk muslim, ia turut mempelopori penyebaran Islam di Jawa dan Sumatera, karena kedatangannya ke nusantara terjadi sebelum adanya Wali Songo. Selain agama Islam dan kebudayaan tionghoa, penjelajahan Laksamana Cheng Ho juga meninggalkan unsur-unsur materiil pada wilayah yang disinggahinya di nusantara. Ketika berkunjung ke Samudera Pasai (Aceh), ia menghadiahi Sultan Samudera Pasai sebuah lonceng raksasa "Cakra Donya" yang hingga kini masih tersimpan di Museum Aceh. Ketika berlabuh di Cirebon, Laksamana Cheng Ho juga menghadiahi Raja Cirebon cinderamata dari Tiongkok, salah satunya berupa piring bertuliskan Ayat Kursi. Nama Laksamana Cheng Ho juga dipakai sebagai nama sebuah Masjid di Jawa Timur dan sebuah Kelenteng di Semarang. Di Palembang sendiri, nama Laksamana Cheng Ho diabadikan sebagai nama sebuah masjid berarsitektur tionghoa di wilayah Jakabaring. Terhitung sejak pelayaran pertama hingga ketujuhnya, Laksamana Cheng Ho dan armadanya pernah mengunjungi Kota Palembang sebanyak empat kali. Pada masa Kerajaan Sriwijaya masih berkuasa, Laksamana Cheng Ho berjasa dalam menumpas perompak Tiongkok bernama Chen Tsu Ji yang kerap menyamun pedagang yang melintas di wilayah Muara Sungai Musi.

\section{Laksamana Cheng Ho di Cirebon}

Cirebon ikut memetik keuntungan dari ekspedisi Laksamana Cheng Ho ke Pulau Jawa. Niat awal sekadar mengisi air bersih, tapi berkembang menjadi penularan ilmu 
menangkap ikan, bertani, dan kesyahbandaran. Bahkan, persahabatan dengan Tiongkok berlanjut hingga masa Sunan Gunung Jati. Salah satu kota penting di Jawa yang menjadi jujukan Laksamana Cheng Ho adalah Cirebon. Penting dalam konteks penyebaran Islam di kawasan Asia Tenggara. Laksamana Cheng Ho dan pasukannya mendatangi Cirebon tahun 1405 pada pelayaran pertamanya. Mereka datang hanya untuk mengisi air bersih bagi kepentingan pasukan. Namun, mengisi air untuk armada Laksamana Cheng Ho tentu membutuhkan waktu lama. Sebab, kapal-kapalnya besar dan jumlah penumpangnya banyak. Singgah di wilayah dalam waktu lama tentu harus minta izin kepada penguasa lokal. Itulah awal persahabatan Laksamana Cheng Ho dengan Cirebon. Saat itu kesultanan Cirebon belum ada, masih di bawah kekuasaan Kerajaan sing Apura (bagian dari Kerajaan Pajajaran).

Pada tahun 1430, kerajaan Cirebon berdiri, dimulai ketika putra Kerajaan Pajajaran Pangeran Cakrabuana mendirikan Keraton Pakungwati. Menurut Sultan Sepuh XIV Keraton Kesepuhan Cirebon Pangeran Raja Adipati Arief Natadiningrat dalam artikel INDOPOS 2017, hampir semua wilayah Cirebon pernah didatangi Laksamana Cheng Ho. Tetapi, daerah yang menjadi tempat tinggal selama di Cirebon adalah kawasan Muara Jati. Daerah itu sekarang menjadi area makam Sunan Gunung Jati. Secara resminya, Laksamana Cheng Ho memberikan hadiah kepada kerjaan Cirebon berupa guci dan piring-piring dengan lafaz tauhid. Kini bendabenda tersebut masuk dalam pusaka keramat Kesultanan Kasepuhan Cirebon yang hanya boleh dilihat pada Jumat. Benda-benda tersebut disimpan dalam museum benda pusaka Kesultanan Kasepuhan Cirebon. Di dalam museum itu ada satu ruangan yang digembok dan hanya dibuka pada Jumat. Ruangan itulah tempat menyimpan piring hadiah Laksamana Cheng Ho dan pusaka keramat lainnya.

Laksamana Cheng Ho juga banyak memberikan bantuan alih teknologi ke masyarakat Cirebon. Di antaranya adalah pembuatan jala penangkap ikan. Sehingga hasil tangkapan nelayan Cirebon menjadi lebih banyak. Bukan hanya itu, Laksamana Cheng Ho juga mengajarkan teknik bercocok tanam. Bagi Kesultanan Cirebon, Laksamana Cheng Ho selalu mencerdaskan bangsa dan masyarakat yang dia kunjungi. Sifatnya bukan eksploitatif, tapi mutualisme. Masyarakat mana pun yang dikunjunginya pasti beruntung. Hubungan Cirebon dengan Tiongkok tidak hanya sampai pada kunjungan Laksamana Cheng Ho. Laksamana Cheng Ho dan armadanya membangun mercusuar untuk mempermudah dalam mengontrol Pelabuhan Muara Jati. Setelah dibangun mercusuar, makin ramailah Pelabuhan Muara Jati sehingga terkenal di seantero Jawa, bahkan mancanegara. Menurut naskah Purwaka Caruban Nagari, armada Laksamana Cheng Ho bersama Ma Huan, penulis dan penerjemahnya yang beragama Islam, mampir ke Cirebon membawa 63 perahu dengan 23.000 anggota pasukan. Meski sempat lama singgah di Cirebon, tidak banyak petilasan Laksamana Cheng Ho di daerah tersebut. Yang masih bisa dijumpai adalah bekas mercusuar di kawasan Muara Jati. Mercusuarnya sendiri sudah roboh pada zaman Belanda. Kini satu-satunya landmark justru bangunan modern berupa replika kapal yang dibangun pengusaha Cirebon keturunan Tionghoa. Yakni restoran berupa replika kapal Cheng Ho yang dibangun persis di pinggir laut. Kesultanan Cirebon menyayangkan bahwa spirit Cheng Ho sangat kuat di Cirebon, namun peninggalannya nyaris tidak ada.

Teori: 


\section{Seni Batik}

Batik dalam ilmu tekstil merupakan teknik reka latar rintang merupakan hasil dari teknik penambahan sebuah material lainnya. Teknik ini menciptakan hasil yang tidak dapat diprediksi namun menarik. Teknik rintang dimaksudkan untuk menciptakan hasil yang sulit direplikasi, namun ini juga berarti memungkinkan munculnya hasil yang tak terduga (McElroy dan Wilson, 2011: 10). Batik Indonesia memiliki ragam corak dan warna dipengaruhi oleh berbagai akulturasi. Pada awalnya, batik memiliki ragam corak dan warna yang terbatas, dan beberapa corak hanya boleh dipakai oleh kalangan tertentu. Namun batik pesisir menyerap berbagai pengaruh luar, seperti para pedagang asing dan juga pada akhirnya, para penjajah.

Warna-warna cerah seperti merah dipopulerkan oleh orang Tionghoa, yang juga mempopulerkan corak phoenix. Bangsa penjajah Eropa juga mengambil minat kepada batik, dan hasilnya adalah corak bebungaan yang sebelumnya tidak dikenal (seperti bunga tulip) dan juga benda-benda yang dibawa oleh penjajah (gedung atau kereta kuda), termasuk juga warna-warna kesukaan mereka seperti warna biru. Batik tradisonal tetap mempertahankan coraknya, dan masih dipakai dalam upacara-upacara adat, karena biasanya masing-masing corak memiliki perlambangan masing-masing.

Batik (atau kata Batik) berasal dari bahasa Jawa "amba" yang berarti menulis dan "titik". Kata batik merujuk pada kain dengan corak yang dihasilkan oleh bahan "malam" (wax) yang diaplikasikan ke atas kain, sehingga menahan masuknya bahan pewarna (dye), atau dalam Bahasa Inggrisnya "wax-resist dyeing". Batik Indonesia adalah kerajinan yang memiliki nilai seni tinggi dan telah menjadi bagian dari budaya Indonesia (khususnya Jawa) sejak lama. Perempuan-perempuan Jawa di masa lampau menjadikan keterampilan mereka dalam membatik sebagai mata pencaharian, sehingga di masa lalu pekerjaan membatik adalah pekerjaan eksklusif perempuan sampai ditemukannya "Batik Cap" yang memungkinkan masuknya laki-laki ke dalam bidang ini. Ada beberapa pengecualian bagi fenomena ini, yaitu batik pesisir yang memiliki garis maskulin seperti yang bisa dilihat pada corak "Mega Mendung", dimana di beberapa daerah pesisir pekerjaan membatik adalah lazim bagi kaum lelaki.

Teknik membatik telah dikenal sejak ribuan tahun yang silam. Tidak ada keterangan sejarah yang cukup jelas tentang asal usul batik. Ada yang menduga teknik ini berasal dari bangsa Sumeria, kemudian dikembangkan di Jawa setelah dibawa oleh para pedagang India. Saat ini batik Indonesia bisa ditemukan di banyak negara seperti Indonesia, Malaysia, Thailand, India, Sri Lanka, dan Iran. Selain di Asia, batik Indonesia juga sangat populer di beberapa negara di benua Afrika. Walaupun demikian, batik yang sangat terkenal di dunia adalah batik yang berasal dari Indonesia, terutama dari Jawa.

Tradisi membatik pada mulanya merupakan tradisi yang turun temurun, sehingga kadang kala suatu motif dapat dikenali berasal dari batik keluarga tertentu. Beberapa motif batik dapat menunjukkan status seseorang. Bahkan sampai saat ini, beberapa motif batik tadisional hanya dipakai oleh keluarga keraton Yogyakarta dan Surakarta. Meskipun batik identik dengan pakaian adat Jawa, namun kini batik sudah menjadi pakaian nasional bagi masyarakat Indonesia, bahkan sudah banyak dikenal di mancanegara. Penggunaannyapun tidak lagi sebagai pakaian adat tetapi sudah mengikuti perkembangan mode busana baik bagi wanita maupun pria, bahkan biasa digunakan sebagai desain interior dan perlengkapan rumah tangga.

\section{Bahasa Rupa}


Bahasa rupa adalah sesuatu yang kasat mata dan sebuah representative dengan maksud untuk meyampaikan untuk menyampaikan makna, yang mana di dalamnya terdapat unsur ekspresif, deskriptif, stilasi, estetik, simbolik, dan semiotic yang diwakilkan dalam bentuk sebuah gambar. Bahasa rupa bukanlah apa yang digambar, tapi cara menggambar untuk menyampaikan pesan (Tabrani, 2005). Bahasa rupa dibagi menjadi dua yaitu bahasa rupa modern dari barat dengan sistem menggambar NPMnya (naturalis-prespektif-momenopname) dan bahasa rupa pendahulu dengan sistem menggambar RWD (ruang-waktu-datar) (Tabrani, 2012 : 3). Contoh gambar NPM adalah foto, lukisan atau ilustrasi yang mengandung still-life dan perspektif sedangkan contoh gambar RWD adalah gambar primitif, wayang dan gambar anak, RWD tidak memiliki batas ruang dan waktu sehingga gambar-gambarnya tidak 'terpenjara' oleh frame. Keunggulan gambar RWD adalah dapat bercerita lebih baik daripada NPM, karena RWD memiliki sifat umum gambar berulang, gambar $x$-ray dan gambar diperbesar-diperkecil tanpa harus memperhitungkan besar objek sebenarnya sehingga menghasilkan gambar yang unik dan dinamis. Sedangkan bahasa rupa NPM yaitu menggambar sesuai dengan apa yang dilihat oleh mata dan memiliki perspektif pada gambarnya sehingga gambarnya masih 'terpenjara' frame.

Klasifikasi Bahasa Rupa:

\section{Naturalis-Perspektif-Momenopname (NPM)}

Masyarakat Yunani yang berfikir "Antropos" dimana semua didasarkan pada manusia, menggambar = seperti dilihat oleh mata - yang dikenal sebagai Naturalis. Sistem NPM menggambarkan dari satu tempat/arah/ waktu. Apa yang digambar di"abadi"kan jadi sebuah adegan yang berupa gambar mati (still picture), dimana gambar di" penjara"kan dalam sebuah bingkai (frame). Senirupa Barat sejak Renesan memakai sistem menggambar NPM. Adapun ciri-ciri spesifik NPM adalah ditarik dari satu perspektif, menghilangkan dimensi waktu, dan memenangkan ruang sehingga mampu mengvisualisasikan tiga dimensi meski dalam wujud dua dimensi (Primadi dalam Girindra Wradhana, 2009).

\section{Ruang-Waktu-Datar (RWD)/Bahasa Rupa Tradisi}

Manusia sejak jaman prasejarah, cenderung berfikir "Kosmos", holistik, total. Seluruh dunia, termasuk barat, menggambar dengan sistem ruang-waktu-datar. Karena berdimensi waktu, maka bisa bercerita. Hal ini bisa dilihat dalam berbagai gambar-gambar di dalam gua prasejarah, yang lebih jelas terlihat dalam relief borobudur. Sistem RWD menggambar dari berbagai tempat / arah / waktu. Gambar yang dihasilkan berupa sekuen yang bisa terdiri dari beberapa adegan, dan gambar tidak di"penjara" dalam frame, tapi "bergerak" dalam ruang dan waktu. Seni visual ini lebih sering bercerita dalam dua dimensi meskipun berwujud tiga dimensi (Primadi dalam Girindra Wardhana, 2009). Dalam Bahasa Rupa ada istilah Wimba, isi Wimba adalah objek yang ada pada gambar atau objek yang digambar.

Cara menyusun berbagai Wimba dengan cara Wimbanya dalam suatu gambar disebut Tata Ungkapan Dalam, sedangkan perubahan isi Wimba, Cara Wimba lengkap dengan Tata Ungkapan Dalam antara gambar yang satu ke yang berikut pada suatu rangkaian gambar (relief, komik, film, tv) disebut Tata Ungkapan Luar. Profesor Primadi Tabrani telah mengembangkan perbendaharaan Bahasa Rupa dwimatra representatih deskriptif statis dan dinamis yang mencakup gambar prasejarah sampai modern. Bahasa Rupa dwimatra deskriptif statis telah ditemukan di Wayang Beber. 
Gambar pra-sejarah, primitif, tradisional, pelukis pelopor, lebih dekat dengan sistem RWD, dengan aneka arah-jarakwaktu, daripada sistem NPM orang dewasa, yang berasal dari barat dan hanya memilik satu arah-jarak-waktu. Musik, drama, sastra bermatra waktu, sehingga bisa bercerita, maka pada sistem RWD, yang bermatra waktu, gambar juga dapat bercerita. Kedua sistem tersebut sudah digunakan dalam kombinasi di seni rupa dan desain masa lalu, masa kini dan akan berlanjut ke masa depan. Namun, ada juga cara Ruang Angkasa, Berkeliling, Aneka Tampak, Diperbesar, Sinar X, yang seluruhnya adalah cara RWD, hal ini merupakan kombinasi NPM dan RWD. Pada objek-objek pra-sejarah, objeknya biasanya dapat dikenali namun mengalami stilasi, yang berarti RWD. Begitu juga pada relief mesir kuno, semua objek dapat dikenali yang berarti naturalis, namun raja dan ratu atau objek manusia apapun biasanya memiliki aneka tampak (tampak muka dan samping), hal ini dikarenakan masyarakat Mesir Kuno ingin memperlihatkan hal yang memiliki nilai penting pada gambar tersebut (Tabrani, 2014:131).

\section{PEMBAHASAN}

Daerah pembatikan Cirebon adalah Desa Trusmi dan Kelitengah. Di kedua desa ini, para wirausahawan santri membangun usaha pembatikan kecil dan besar. Karena itu, status perusahaan mereka dapat digolongkan sebagai perusahaan menengah dan kecil. Batik Cirebon tidak terlepas dari perkembangan sejarah cirebon sebagai kerajaan Islam kedua di tanah Jawa setelah Demak. Kerajaan Cina Selatan, yang sebagian masyarakatnya termasuk kalangan bangsawannya, telah memeluk Islam. Hubungan akrab dengan Cina diperkokoh dengan perkawinan antara Sunan Gunung Jati, sebagai raja Cirebon, dan puteri kaisar Cina, yang bernama Ong Tien, atau Putri Cina (Paramita R. Abdurachman, 1982).
Imigran dari Cina juga banyak yang menetap di Cirebon, khususnya di Kanduruan.

Cirebon, sebagai kerajan Islam, mengembangkan corak kebudayaan khas yang berbeda dari kerajaan lain, seperti Demak dan Mataram, Dari mulai wayang kulit, musik (gamelan), tari topeng dan wayang, ukiran, lukisan kaca, hingga batik, memiliki corak yang berbeda dari daerah lain. Ragam hias Cirebon, yang masih dapat kita lihat pada benda-benda pusaka dan ukiran di keraton Cirebon, menunjukkan gaya paduan ragam hias Cina. Ragam hias itu banyak dijumpai pada keramik cina yang banyak ditemukan pada dinding bangunan, seperti masjid, keraton, dan makam. Ragam hias Cina juga masih dapat kita amati pada peninggalan kostum cina yang disulam dengan aneka warna benang dan pada benda-benda di kelenteng. Benda-benda ini memperlihatkan gaya lengkungan yang dinamis. Ragam hias Cina banyak kemiripannya dengan ragam hias Cirebon. Ciri menonjol ragam hias cirebon adalah garisgaris lengkung bergelombang, yang banyak dipakai untuk menggambarkan bentuk awan, dan wadasan (cadas) yang tersusun ritmis.

Ada dua ciri yang sangat menonjol pada batik Cirebon, yaitu batik keraton dan batik bang biron. Batik keraton Cirebon memiliki ciri warna putih (dasar), biru (indigo) dan coklat (soga). Ragam hias yang dipilih banyak terkait dengan mitologi yang berkembang di cirebon, seperti paksi naga liman, singa barong, taman arum, naga seba, dan sebagainya. Tata letak batik keraton cirebon, umumnya tersusun horizontal tiga saf, yang menggambarkan jajaran atas, tengah, dan bawah. Ragam hias batik Cirebon umumnya menggambarkan pemandangan alam yang berhubungan dengan mitologi tempat yang dianggap penting. Ciri tempat tersebut adalah berbatu cadas (wadasan). Penggambaran keadaan alam dengan jajaran gambar horizontal mengingatkan pada konsep 
ruang atau perspektif timur (Cina) yang membagi ruang (jarak) jauh yang diletakkan pada bagian atas, dan ruang (jarak) dekat yang diletakkan pada bagian bawah. Tekanan warna yang digunakan untuk itu adalah sama.

Batik bang biron, atau batik berwarna merah (mengkudu) dan biru (nila), menjadi ciri utama batik pesisiran. Ragam hias pada batik bang biron umumnya flora atau fauna yang distilasi. Batik ini dikerjakan dalam dua kali babaran. Pertama-tama kain itu dibabar dengan warna merah, dibatik lagi, kemudian dicelupun dengan warna biru, bahkan kadangkala dicelup dengan warna kuning (tageran). Dengan demikian, akan terjadi persilangan warna yaitu merah, biru, hitam, dan hijau, dengan dasar putih.

\section{Studi Komparasi Bahasa Rupa pada Tiga Batik Cirebon}

(Berdasarkan tabel cara Wimba dan Tata Ungkapan dalam buku berjudul Bahasa Rupa karya Primadi Tabrani, 2012 dari Penerbit Kelir, halaman 191, 192 dan 193.)

\section{Batik Kompeni}

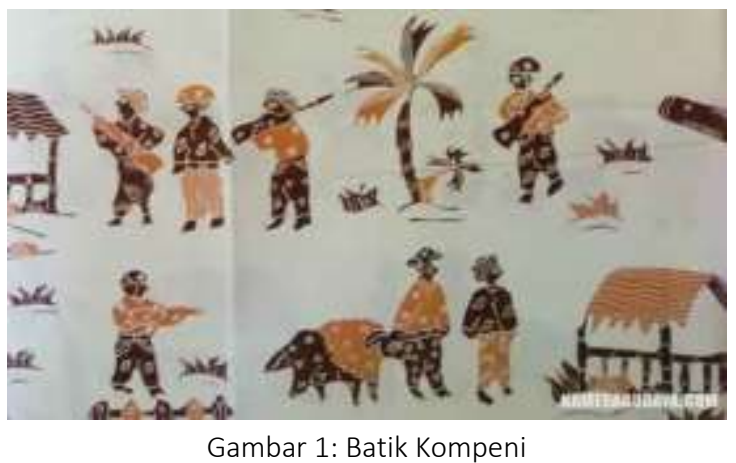

(Sumber:https://www.cintaindonesia.web.id/2018/06/m otif-motif-batik-cirebon-yang-terkenal.html)

Batik kompeni berbeda dengan motif batik lain. Motif batik pesisir lainnya lebih menitikberatkan pada ornament flora dan fauna serta berbagai bentuk symbol tertentu. Sedangkan batik kompeni memiliki motif berupa gambar yang bercerita. Batik kompeni menggambarkan perang pada jaman kolonial
Belanda. Motif batik yang muncul berupa gambar meriam, truk, tank, bambu runcing dan senapan. Ciri batik kompeni adalah menggambarkan tentara VOC dan penduduk semasa panjajahan dulu. Tentara VOC biasanya digambarkan dengan senapan laras panjang dan meriam. Sedangkan penduduk digambarkan melalui kehidupan petani, nelayan dan pedagang. Warna latar kain batik kompeni yang biasanya dibiarkan berwarna putih, juga menjadi ciri khas batik kompeni ini. Namun, dijumpai pula batik kompeni yang latarnya diberi warna.

Pengamatan Bahasa Rupa: Termasuk dala cara wimba dengan skala yaitu manusia digambar lebih besar dari aslinya jika di bandingkan dengan pohon dan gubuk. Ini menandakan bahwa manusia "lebih penting" disini untuk menceritakan suatu kejadian. Penggambaran ini juga termasuk dalam cara wimba penggambaran kejadian. Manusia di gambar berjejer dengan jelas menceritakan apa yang sedang terjadi walaupun gerak tidak dinamis atau berulang. Sedangkan pohon, gubuk dan semak digambarkan lebih kecil namun tidak terlalu jauh perbandingannya dengan manusia karena ingin menceritakan suasana dan tempat.

\section{Batik Paksi Naga Liman}

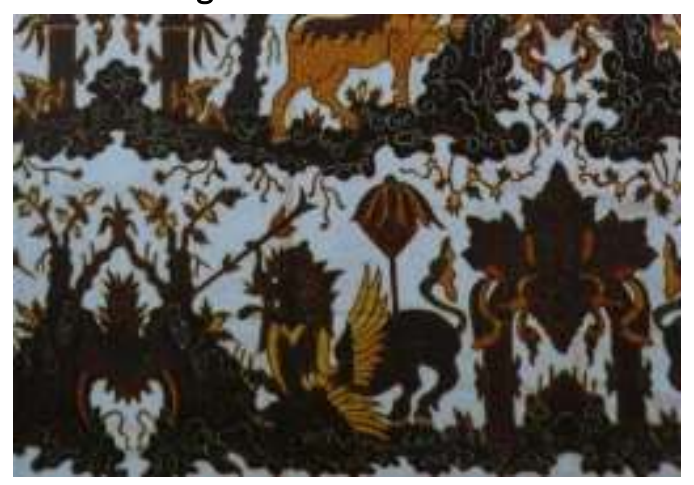

Gambar 2: Batik Paksi Naga Liman

(Sumber: https://infobatik.id/batik-cirebon-motif-paksinaga-liman/)

Batik paksinaga liman bermotif kereta kencana paksi naga liman Cirebon. Paksinaga 
liman merupakan perwujudan gabungan antara binatang paksi (garuda), naga (ular) dan liman (gajah). Paksi naga liman adalah simbol kekuatan kerajaan Cirebon yakni udara (paksi), laut (naga) serta darat (liman). Batik paksi naga liman biasa dipesan oleh turis Jepang untuk dijadikan bahan kimono.

Pengamatan Bahasa Rupa: Wimba yang penting disini adalah paksi naga liman di gambarkan lengkap dari kepala sampai kaki, Paksi naga liman adalah perwujudan gabungan antara garuda, ular dan gajah ini digambar menjadi satu makhluk yang memiliki sayap mewakili garuda, belalai dan gading mewakili gajah sedangkan sisik dan ekor api mewakili naga. Ini termasuk dalam bahasa rupa dengan penggambaran penggabungan dan perwakilan dalam suatu wimba (objek). Sedangkan untuk tata ungkapan luar terdapat taman yang ditandai oleh pohon dan tanaman.

\section{Batik Taman Arum Sunyaragi}

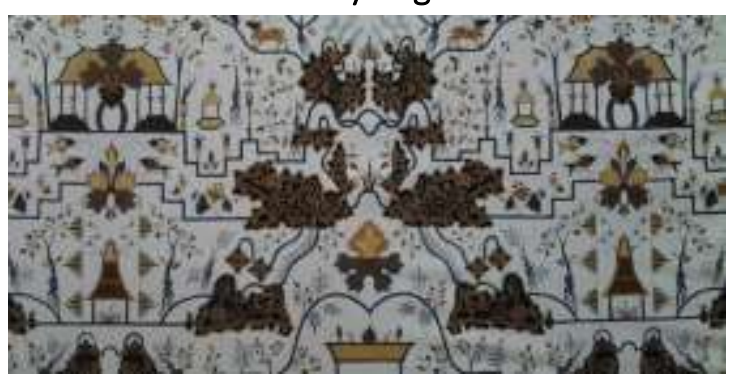

Gambar 3. Batik Taman Arum Sunyaragi

(Sumber: http://sanggarbatikkatura.com/tag/kategoribatik)

Motif batik Taman Arum Sunyaragi berkisah tentang kawasan taman yang masih berhubungan dengan Keraton. Konon, taman ini dulunya digunakan oleh para Sultan untuk bertapa dan merelaksasikan jiwa. Taman Arum berarti taman yang harum dan asri. Nama dari taman tersebut adalah Goa Sunyaragi (Sunya= Sunyi/sepi; Ragi=Raga). Dalam motif Taman Arum Sunyaragi ini digambarkan jelas lingkungan Taman Sunyaragi dengan segala aktivitas flora dan faunanya. Meskipun motif batik ini terdapat flora dan fauna, akan tetapi motif ini tetap termasuk dalam kategori batik Keratonan karena Taman Arum Sunyaragi merupakan situs yang masih berhubungan dengan keraton. Pakem warna dari motif batik ini layaknya karakteristik warna pada kategori batik Keratonan, yaitu coklat, krem, dan hitam. Namun, seiring dengan perkembangan zaman maka motif Taman Arum Sunyaragi dapat dimodifikasi sesuai selera, misalnya menjadi warna biru ataupun warna lain.

Pengamatan Bahasa Rupa: Semua wimba yang terdapat pada batik ini digambarkan dengan tata ungkapan dalam menyatakan ruang, yaitu digambar secara rebahan dan $x$-ray pada kolam dimana terlihat ikan dan isi kolam yang juga digambar rebahan, yang ingin menyatakan secara jelas bahwa itu adalah kolam. Sedangkan pada tata ungkapan luar yang ingin disampaikan adalah suasana taman dengan penggambaran komposisi yang berulang. 


\begin{tabular}{|c|c|c|c|c|}
\hline $\begin{array}{l}\text { Struktur } \\
\text { Produk }\end{array}$ & Batik Kompeni & Batik Paksinaga Liman & $\begin{array}{c}\text { Batik Taman Arum } \\
\text { Sunyaragi }\end{array}$ & Analisis \\
\hline Unsur Batik & $\begin{array}{l}\text { Ornamen diletakkan } \\
\text { secara renggang. } \\
\text { Terdapat ornamen } \\
\text { manusia, tumbuhan, } \\
\text { hewan dan benda- } \\
\text { benda keseharian } \\
\text { pekerja pribumi dan } \\
\text { benda-benda yang } \\
\text { dibawa oleh kompeni. }\end{array}$ & $\begin{array}{l}\text { Ornamen yang ada di } \\
\text { Keraton. Paksi (burung } \\
\text { garuda), Naga (ular besar) } \\
\text { dan Liman (gajah), kereta } \\
\text { kencana kerajaan, mega } \\
\text { mendung dan hiasan } \\
\text { tanaman. }\end{array}$ & $\begin{array}{l}\text { Ornamen yang ada di } \\
\text { Keraton. Taman kerajaan, } \\
\text { flora dan fauna, mega } \\
\text { mendung. }\end{array}$ & \\
\hline $\begin{array}{l}\text { Gaya Visual } \\
\text { dan Bahasa } \\
\text { Rupa }\end{array}$ & $\begin{array}{l}\text { Gaya kontemporer, } \\
\text { bersifat bebas, gambar } \\
\text { seperti bercerita } \\
\text { tentang kehidupan } \\
\text { sehar-hari orang } \\
\text { belanda dan pribumi. } \\
\text { Gaya gambar bersifat } \\
\text { naturalis perspektif } \\
\text { momenopname dan } \\
\text { ruang waktu datar, } \\
\text { perbandingan besar } \\
\text { kecil pada objek } \\
\text { gambar dengan } \\
\text { ukuran sebenarnya } \\
\text { tidak berlaku (RWD). }\end{array}$ & $\begin{array}{l}\text { Gaya batik tradisional, } \\
\text { ornament yang ada di } \\
\text { keratonan, ornament di } \\
\text { gambar bersifat naturalis } \\
\text { perspektif momenopname } \\
\text { dan ruang waktu datar } \\
\text { terbagi-bagi atas, tengah dan } \\
\text { bawah. }\end{array}$ & $\begin{array}{l}\text { Gaya batik tradisional, } \\
\text { ornament yang ada di } \\
\text { keratonan, setiap } \\
\text { ornament dibuat seperti } \\
\text { bahasa rupa ruang waktu } \\
\text { datar. Tidak ada } \\
\text { perspektif (semua objek } \\
\text { terlihat seperti merebah) }\end{array}$ & $\begin{array}{l}\text { Batik pesisiran dan } \\
\text { batik tradisional } \\
\text { keratonan cirebon } \\
\text { memiliki sistem } \\
\text { penggambaran } \\
\text { bahasa rupa NPM } \\
\text { maupun RWD. }\end{array}$ \\
\hline Komposisi & $\begin{array}{l}\text { Penataan ornamen } \\
\text { yang sama atau motif } \\
\text { ulang yang ditata agak } \\
\text { renggang, namun } \\
\text { bersifat bebas }\end{array}$ & $\begin{array}{l}\text { Dua objek yang sama } \\
\text { berhadap-hadapan (mirror), } \\
\text { seperti bertingkat. }\end{array}$ & $\begin{array}{l}\text { Dua objek yang sama } \\
\text { berhadap-hadapan } \\
\text { (mirror), seperti } \\
\text { bertingkat. }\end{array}$ & \\
\hline Jenis Batik & Batik Cirebonan & Batik Keratonan & Batik Keratonan & \\
\hline Motif & $\begin{array}{l}\text { Motif batik yang } \\
\text { muncul berupa } \\
\text { gambar meriam, truk, } \\
\text { tank, bambu runcing } \\
\text { dan senapan }\end{array}$ & $\begin{array}{l}\text { - Motif mega mendung } \\
\text { corak khas Cirebon } \\
\text { - Nampak juga pengaruh } \\
\text { budaya Islam (Arab), Hindu } \\
\text { (India) dan Tiongkok yang } \\
\text { digambarkan dalam kereta } \\
\text { kencana yang ditarik oleh } \\
\text { binatang mistik Paksi Naga } \\
\text { Liman. } \\
\text { - Sementara elemen budaya } \\
\text { Eropa nampak begitu jelas } \\
\text { dalam penggambaran } \\
\text { burung dengan sayap yang } \\
\text { tampak sebagai emblem. }\end{array}$ & $\begin{array}{l}\text { Terdapat motif mega } \\
\text { mendung, taman, flora } \\
\text { dan fauna. Juga ada motif } \\
\text { seperti gapura pada } \\
\text { bagian bawah dan } \\
\text { terdapat beberapa } \\
\text { tempat seperti sawung. }\end{array}$ & \\
\hline Teknik & Batik Tulis & Batik Tulis dan Batik Cap & Batik Tulis dan Batik Cap & \\
\hline Warna & $\begin{array}{l}\text { Warna khas pesisiran } \\
\text { yang bebas, biasanya } \\
\text { bewarna terang } \\
\text { seperti merah, kuning, } \\
\text { biru, hijau dan lainnya. }\end{array}$ & $\begin{array}{l}\text { Warna keratonan yang } \\
\text { banyak biasanya bewarna } \\
\text { coklat, krem, hitam dan soga, } \\
\text { namun biasanya ada warna } \\
\text { kebiruan (indigo) dan } \\
\text { kemerahan. }\end{array}$ & $\begin{array}{l}\text { Warna keratonan yang } \\
\text { banyak biasanya bewarna } \\
\text { coklat, krem, hitam dan } \\
\text { soga. }\end{array}$ & $\begin{array}{l}\text { Warna pada batik } \\
\text { pesisiran yang lebih } \\
\text { bervariasi dan berani } \\
\text { karena dipengaruhi } \\
\text { oleh lingkungan dekat } \\
\text { dengan pelabuhan } \\
\text { dimana sering terjadi } \\
\text { pengaruh kebudayaan } \\
\text { dari bangsa lain yang }\end{array}$ \\
\hline
\end{tabular}




\begin{tabular}{|c|c|c|c|c|}
\hline $\begin{array}{c}\text { Makna } \\
\text { Batik }\end{array}$ & $\begin{array}{l}\text { Batik kompeni } \\
\text { menggambarkan } \\
\text { perang pada jaman } \\
\text { kolonial Belanda. Pada } \\
\text { motif ini terlihat } \\
\text { gambar tentara yang } \\
\text { sedang memegangi } \\
\text { senjata dan } \\
\text { masyarakat pribumi } \\
\text { yang seakan-akan } \\
\text { dipaksa melakukan } \\
\text { pekerjaan serta } \\
\text { berbagai macam } \\
\text { aktivitas lainnya } \\
\text { dimasa lampau. }\end{array}$ & $\begin{array}{l}\text { Paksi (burung garuda): badan } \\
\text { bersayap ini mengartikan } \\
\text { bahwa unsur Islam pertama } \\
\text { diturunkan di Timur Tengah } \\
\text { dan menunjukkan hubungan } \\
\text { dimana ayahanda Sunan } \\
\text { Gunung Jati adalah raja } \\
\text { Mesir, Syarif Abdullah. } \\
\text { Naga (ular besar): atau liong } \\
\text { yang telah mahfum sebagai } \\
\text { simbolisasi atas negri } \\
\text { Tiongkok dan kandungan } \\
\text { anasir Budha juga } \\
\text { menunjukkan bahwa salah } \\
\text { satu istri Sunan Kalijaga } \\
\text { berasal dari Cina yaitu Ong } \\
\text { Tien Nio alias Rara } \\
\text { Sumanding. } \\
\text { Liman (gajah): yang artinya } \\
\text { belalai adalah gajah simbol } \\
\text { Ganesha sebagai putra Dewa } \\
\text { Syiwa dari negri Hindustan } \\
\text { (India) yang juga membawa } \\
\text { pengaruh unsur Hindu. } \\
\text { Bahkan, berkembang } \\
\text { penafsiran atas makna Paksi } \\
\text { Nga Liman yang } \\
\text { mengisyaratkan kejayaan } \\
\text { kedaulatan secara } \\
\text { menyeluruh. Burung penjaga } \\
\text { kedaulatan di udara (Jaya } \\
\text { Dirgantara), Naga penjaga } \\
\text { kedaulatan laut (Jaya Bahari) } \\
\text { dan Gajah penjaga } \\
\text { kedaulatan di darat (Jaya } \\
\text { Bhumi). } \\
\text { Ketiga binatang yang } \\
\text { memiliki kekuatan yang } \\
\text { sangat besar apabila } \\
\text { dipadukan. }\end{array}$ & $\begin{array}{l}\text { Taman Arum Sunyaragi } \\
\text { berkisah tentang kawasan } \\
\text { taman yang masih } \\
\text { berhubungan dengan } \\
\text { Keraton. Konon, taman ini } \\
\text { dulunya digunakan oleh } \\
\text { para Sultan untuk bertapa } \\
\text { dan merelaksasikan jiwa. }\end{array}$ & $\begin{array}{l}\text { Dari zaman kerajaan } \\
\text { sampai zaman } \\
\text { penjajahan, dari suatu } \\
\text { kejadian nyata atau } \\
\text { mitos, batik Cirebon } \\
\text { menggambarkan } \\
\text { kondisi, tempat } \\
\text { maupun artefak. } \\
\text { Semua pada } \\
\text { zamannya manusia } \\
\text { ingin mencoba } \\
\text { melestarikan apa yang } \\
\text { terjadi padanya dan } \\
\text { lingkungannya, dan } \\
\text { ingin mengetahui } \\
\text { identitas melalui } \\
\text { sejarah dan mencoba } \\
\text { melestarikannya } \\
\text { untuk generasi } \\
\text { selanjutnya agar tidak } \\
\text { hilang. Semua itu } \\
\text { digambarkan dalam } \\
\text { batik Cirebon. }\end{array}$ \\
\hline
\end{tabular}

pada akhirnya warga

Cirebon disana

seringkali

menggambarkan

ornament yang

natural dengan warna

yang berani.

Sedangkan batik

keratonan yang

dibuat di lingkungan

keraton jauh dari

pesisir sehingga

warna-warna yang

dihasilkan warna-

warna kekeratonan

dan warna

lingkungannya. 
PENUTUP

Dari ketiga batik di atas, baik cirebonan maupun batik keratonan ketiganya memiliki cara penggambaran Bahasa Rupa Tradisi. Unsur narasi ternyata memang sudah digunakan pada berbagai corak yang dikaitkan dengan legenda masa kejayaan kerajaan Cirebon. Begitu juga dengan batik pesisiran kompeni juga memiliki narasi yang lebih jelas dan dengan gestur yang komunikatif. Cerita kekeratonan Cirebon maupun cerita saat zaman penjajahan Belanda semua di abadikan melalui batik dan terjaga sampai sekarang, Maka dari itu, perancangan batik dengan kisah sejarah menggunakan sistem penggambaran Bahasa Rupa Tradisi dapat melestarikan peninggalan sejarah untuk memperkaya khasanah kebudayaan bangsa Indonesia terutama untuk Cirebon sekaligus melestarikan Bahasa Rupa Tradisi yang merupakan sistem menggambar yang dianut oleh seni rupa tradisi Indonesia sejak zaman dahulu.

\section{DAFTAR PUSTAKA}

Gunawan, Imam. 2015. Metode Penelitian Kualitatif: Teori dan Praktik. Jakarta: Bumi Aksara.

Hasanudin, Drs. M.Sn. 2001. Batik Pesisiran: Melacak Pengaruh Etos Dagang Santri pada Ragam Hias Batik. Bandung: PT.Kiblat Buku Utama.

Lubis, Mochtar. 1977. Manusia Indonesia. Jakarta: Idayu Press.
Tabrani, Prof. Dr, H. Primadi. 2012. Bahasa Rupa, Bandung: Penerbit Kelir.

Tabrani, Prof. Dr. H. Primadi. 2014. Proses Kreasi Gambar Anak Proses Belajar. Bandung: Erlangga.

Wilson, Jacquie. 2001. Handbook of Textile Design. Cambridge: Woodhead Publishing Limited.

\section{SUMBER INTERNET}

Girindra Wardhana, Timur. 2009. Berkenalan dengan Bahasa Rupa. url: https://timurizer.wordpress.com/2009 /09/25/berkenalan-denganbahasarupa/, diakses pada tanggal 20 Februari 2018, 16:46.

Sultan Sepuh XIV Keraton Kesepuhan Cirebon Pangeran Raja Adipati Arief Natadiningrat dalam INDOPOS. 2017. Menelusuri Jejak Laksamana Cheng Ho di Kawasan Cirebon. url: https://indopos.co.id/read/2017/06/2 3/102412/menelusuri-jejaklaksamana-cheng-ho-di-kawasancirebon, diakses pada tanggal 19 Februari, 17:30. 